\title{
A Study on Correlation of Orgware Indicators with Socio-Personal, Communication and Pyschological Profile
}

\author{
Jitendra Pal Ghatawal* and Basavaprabhu Jirli \\ Department of Extension Education, Institute of Agricultural sciences, Banaras Hindu \\ University, Varanasi, 221005, India \\ *Corresponding author
}

\section{A B S T R A C T}

\section{Keywords \\ Orgware, Capability, Socio- personal, Communication, Psychological, \\ Questionnaire, Ex-post facto, Correlation co- efficient, Humanware \\ Article Info \\ Accepted: \\ 15 September 2018 \\ Available Online: \\ 10 October 2018}

\begin{abstract}
The mere development of hardware and software mediated technologies for performing operational task is not sufficient to increase organizational performance many folds, but also it requires the development of capabilities of humanware for handling these hardware and software mediated technologies. This study was conducted at Central office of Banaras Hindu University, Varanasi; UP on 208 section officer, senior assistant, senior clerk and junior clerk from all four cells and four offices. Data were collected through the method of whole enumeration using a well-structured questionnaire and ex-post facto research design was used. The relationship between indicators of Orgware and factors of Socio-personal, Communication and Psychological profile was worked out with the help of correlation coefficient to know the extent of the relationship between the profile variables and indicators of orgware. Majority of the profile factors of humanware had significant effect on the orgware in turn also on organizational performance.
\end{abstract}

\section{Introduction}

Over the past few years in organizational working attention is constantly being given on the automation of working procedures along with on the skill and capability development of the concerned humanware to handle required hardware and software effectively and efficiently. Without the requisite orgware, it will be difficult for an organization to muster the needed resources to develop and maintain the desired levels of performance. Orgware refers to structures forming the frames of human activities (Ziemba, 2012). One of the indispensible resources in any organization is humanware which needed to be trained to handle these hardware and software in efficient and effective manner.

This efficiency and effectiveness is governed by the indicators of orgware. In this study efforts were made to analyze the correlation between the indicators of Orgware and sociopersonal, communication and psychological profile of humanware. The indicators of orgware largely depend upon these profile factors.

\section{Materials and Methods}

Central office of Banaras Hindu University, Varanasi, UP was provisionally selected as the 
locale of present study. A sample of 208 section officer, senior assistant, senior clerk and junior clerk from all four cells and four offices was selected through method of whole enumeration using a well-structured questionnaire and ex-post facto research design was used.

The relationship between indicators of Orgware and factors of Socio-economic, Communication and Psychological profile was worked out with the help of correlation coefficient which represents the degree of association and dissociation between these dependent and independent variables.

\section{Results and Discussion}

An effort was made to find out the correlation coefficient ( $r$ ) of selected dependent variable viz. Indicators of Orgware with selected independent variables i.e. profile variables to see the degree of association between the selected variables.

\section{Correlation between respondent's socio- economic profile and Indicators of Orgware}

\section{Age and indicators of orgware}

Table 1 showed that there was significant linear relationship between age of the respondents and communication in organization, critical thinking, effectiveness of efficient humanware, job knowledge, teamwork, work environment and decision making in problem solving whereas in case of professionalism the $\alpha(0.05)$ is greater than $p$ value $(0.043)$ so there is no linear relationship between professionalism and age of the respondents.

\section{Background and indicators of orgware}

Table 1 showed that there was significant linear relationship between background of the respondents and communication in organization, critical thinking, effectiveness of efficient humanware, environment and decision making in problem solving whereas in case of job knowledge, teamwork, professionalism the $\alpha(0.05)$ is greater than $p$ value (-0.018), (-0.025), (0.002) respectively so, there is no linear relationship between job knowledge, teamwork, professionalism and background of the respondents. This showed that background of the employees plays an important role in organizational effectiveness and efficiency by influencing the indicators of orgware.

\section{Education and indicators of orgware}

Table 1 showed that there was significant linear relationship between education of the respondents and critical thinking, effectiveness of efficient humanware, team work, professionalism, work environment and decision making in problem solving whereas in case of communication in organization, job knowledge the $\alpha(0.05)$ is greater than $p$ value $(-0.013)$ and (-0.004) respectively so there is no linear relationship between education of respondents and communication in organization, job knowledge.

\section{Income and indicators of orgware}

Table 1 showed that there was significant linear relationship between income of the respondents and job knowledge, work environment and decision making in problem solving whereas in case of communication in organization, critical thinking, effectiveness of efficient humanware, team work and professionalism the $\alpha(0.05)$ is greater than $\mathrm{p}$ value (0.008), (0.003), (0.009), (0.008) and (0.048) respectively so, there is no linear relationship between income of respondents and communication in organization, critical thinking, and effectiveness of efficient humanware, team work and professionalism. 
Table.1 Relationship of the respondent's socio-economic profile with the indicators of orgware

\begin{tabular}{|l|l|l|l|l|l|}
\hline S. & Indicators of Orgware & \multicolumn{3}{|c|}{ Correlation coeficient ' $r$ ' } \\
\cline { 3 - 6 } No & & Age & Background & Education & Income \\
\hline 1. & Communication in organization & $-0.091^{*}$ & $0.057^{*}$ & -0.013 & 0.008 \\
\hline 2. & Critical thinking & $-0.054^{*}$ & $-0.096^{*}$ & $0.051^{*}$ & 0.003 \\
\hline 3. & Effectiveness of efficient Humanware & $0.097^{*}$ & $0.100^{*}$ & $0.083^{*}$ & 0.009 \\
\hline 4. & Job knowledge & $0.054^{*}$ & -0.018 & -0.004 & $-0.109^{*}$ \\
\hline 5. & Teamwork & $0.183^{*}$ & -0.025 & $0.123^{*}$ & 0.008 \\
\hline 6. & Professionalism & 0.043 & 0.002 & $0.135^{*}$ & 0.048 \\
\hline 7. & Work environment & $0.198^{*}$ & $0.065^{*}$ & $0.137^{*}$ & $0.089^{*}$ \\
\hline 8. & Decision making in problem solving & $0.172^{*}$ & $-0.114^{*}$ & $0.082^{*}$ & $0.055^{*}$ \\
\hline *= correlation is significant at 0.05 levels (two- tailed). & & & & \\
\hline
\end{tabular}

Table.2 Relationship of the respondent's communication profile with the indicators of Orgware

\begin{tabular}{|l|l|l|l|l|}
\hline S. No & Indicators of Orgware & \multicolumn{3}{|c|}{ Correlation coefficient ' $r$ ' } \\
\cline { 3 - 5 } & $\begin{array}{c}\text { Mass media } \\
\text { exposure }\end{array}$ & $\begin{array}{c}\text { Interpersonal } \\
\text { communication }\end{array}$ & $\begin{array}{c}\text { Social } \\
\text { participation }\end{array}$ \\
\hline 1. & Communication in organization & 0.056 & $0.082^{*}$ & 0.002 \\
\hline 2. & Critical thinking & 0.016 & -0.047 & $-0.075^{*}$ \\
\hline 3. & Effectiveness of efficient Humanware & -0.009 & $0.135^{*}$ & $0.053^{*}$ \\
\hline 4. & Job knowledge & 0.025 & 0.023 & 0.027 \\
\hline 5. & Teamwork & $0.096^{*}$ & $0.133^{*}$ & 0.008 \\
\hline 6. & Professionalism & 0.029 & $0.173^{*}$ & $0.098^{*}$ \\
\hline 7. & Work environment & $0.101^{*}$ & 0.040 & 0.040 \\
\hline 8. & Decision making in problem solving & $0.189^{*}$ & $0.074^{*}$ & -0.015 \\
\hline *= correlation is significant at 0.05 levels (two- tailed). & & & \\
\hline
\end{tabular}

Table.3 Relation of the respondent's psychological profile with the indicators of Orgware

\begin{tabular}{|c|c|c|c|}
\hline \multirow[t]{2}{*}{ S. No } & \multirow[t]{2}{*}{ Indicators of Orgware } & \multicolumn{2}{|c|}{ Correlation coefficient ' $r$ ' } \\
\hline & & $\begin{array}{l}\text { Achievement } \\
\text { motivation }\end{array}$ & $\begin{array}{l}\text { Level of } \\
\text { Aspiration }\end{array}$ \\
\hline 1. & Communication in organization & $-0.050^{*}$ & $0.079^{*}$ \\
\hline 2. & Critical thinking & -0.025 & $0.069^{*}$ \\
\hline 3. & Effectiveness of efficient Humanware & -0.011 & $0.113 *$ \\
\hline 4. & Job knowledge & $-0.131^{*}$ & $0.141 *$ \\
\hline 5. & Teamwork & $0.108 *$ & $-0.062^{*}$ \\
\hline 6. & Professionalism & $0.054 *$ & -0.023 \\
\hline 7. & Work environment & $0.550^{*}$ & -0.039 \\
\hline 8. & Decision making in problem solving & 0.009 & -0.038 \\
\hline
\end{tabular}




\section{Correlation between respondent's communication profile and indicators of Orgware}

Mass media exposure and indicators of orgware

Table 2 showed that there was significant linear relationship between mass media exposure of the respondents and communication in organization, teamwork, work environment and decision making in problem solving whereas in case of critical thinking, effectiveness of efficient humanware, job knowledge and professionalism the $\alpha(0.05)$ is greater than $p$ value (0.016), (-0.009), (0.025) and (0.029) respectively so, there is no linear relationship between mass media exposure of respondents and critical thinking, and effectiveness of efficient humanware, job knowledge and professionalism.

\section{Inter-personal and indicators of Orgware}

Table 2 showed that there was significant linear relationship between interpersonal communication of the respondents and communication in organization, effectiveness of efficient humanware, teamwork, professionalism and decision making in problem solving whereas in case of critical thinking, job knowledge and work environment the $\alpha(0.05)$ is greater than $p$ value $(-0.047),(0.023)$ and (0.040) respectively so, there is no significant linear relationship between interpersonal communication of respondents and critical thinking, job knowledge and work environment.

Social participation and indicators of Orgware

Table 2 showed that there was significant linear relationship between social participation of the respondents and critical thinking, effectiveness of efficient humanware and professionalism whereas in case of communication in organization, job knowledge, teamwork, work environment and Decision making in problem solving the $\alpha$ $(0.05)$ is greater than $p$ value $(0.002),(0.027)$, $(0.008)$ and $(-0.015)$ respectively so, there is no significant linear relationship between social participation of respondents and communication in organization, job knowledge, teamwork, work environment and Decision making in problem solving

\section{Correlation between respondent's psychological profile and indicators of Orgware}

\section{Achievement motivation and indicators of Orgware}

Table 3 showed that there was significant linear relationship between achievement motivation of the respondents and communication in organization, job knowledge, teamwork, professionalism and work environment whereas in case of critical thinking, Effectiveness of efficient Humanware and Decision making in problem solving the $\alpha(0.05)$ is greater than $p$ value ($0.025),(-0.011)$ and (0.009) respectively so, there is no significant linear relationship between achievement motivation of respondents and critical thinking, Effectiveness of efficient Humanware and Decision making in problem solving.

\section{Level of aspiration and indicators of Orgware}

Table 3 showed that there was significant linear relationship between level of aspiration of the respondents and communication in organization, critical thinking, effectiveness of efficient humanware, job knowledge and teamwork whereas in case of professionalism, 
work environment and Decision making in problem solving the $\alpha(0.05)$ is greater than $p$ value $(-0.023),(-0.039)$ and $(-0.038)$ respectively so, there is no significant linear relationship between level of aspiration of respondents and professionalism, work environment and Decision making in problem solving.

The above results indicate that these profile factors influences orgware of any organization. The automation of working in the organization may it be manufacturing or service sector requires hardware and software mediated technologies. The technologies need trained humanware to be operated. Imparting the training regarding technologies is influenced by a large by the age, education, income, achievement motivation, aspiration, social participation and communication etc. These social, communication and psychological backgrounds decide the innate efficiency and effectiveness of the humanware insuring the better quality output and services from the organizations.

\section{References}

Abugre, J. B. (2011). Appraising the impact of organizational communication on worker satisfaction in organizational workplace. Problems of Management in the 21st Century, 1(1), 7-15.

Dobrov, G. M. (1979). The strategy for organized technology in the light of hard-, soft-, and org-ware interaction. Long Range Planning, 12(4), 79-90.

Farahmand, N. F. H. (2011). Organizational Technology Management by Human ware as important technology factor. analysis, 1(3).

Ghatawal, J.P. and Jirli, B. (2015). Profile of Post graduate students of Agriculture and Journalism and Mass communication students of BHU, Varanasi. Research Journal of Agriculture and Forestry Sciences, Vol. 3(10), 1-10.

Husain, Z. (2013). Effective communication brings successful organizational change. The Business \& Management Review, 3(2), 43.

Nebo, Chidiebere S., Nwakwo, Precious Ngozi and Okonkwo, Rito Ifeoma. (2015). The Role of Ffective Communication on Organizational Performance: A Study of Nnamdi Azikiwe University, AWKA, Review of Public Administration and Management, 4(8), 131-148.

Ziemba, R. (2012). Catastrophe medicine as domain of scientific system. Military Pharmacy and Medicine, 1, 28.

\section{How to cite this article:}

Jitendra Pal Ghatawal and Basavaprabhu Jirli. 2018. A Study on Correlation of Orgware Indicators with Socio-Personal, Communication and Pyschological Profile. Int.J.Curr.Microbiol.App.Sci. 7(10): 1827-1831. doi: https://doi.org/10.20546/ijcmas.2018.710.209 